\title{
LAURIE SHEPARD
}

\section{SIENA 1531: GENESIS OF A EUROPEAN HEROINE}

In Gl'ingannati, Isabella, a wealthy nubile woman of Modena, lures Fabio, the page of a local merchant, into the entryway of her home and there they exchange a kiss and the promise of a tryst. In the sixteenth-century comedy, the kiss took place off stage, recounted and embellished by Crivello and Scatizza, two servant-voyeurs. Fabio is with Isabella at his master Flamminio's bidding, supposedly wooing her for him, but quite obviously helping himself to his "master's dish," as Scatizza puts it. ${ }^{1}$ Isabella is deceived: the young man she lusts after is Lelia, who has disguised herself in male attire in order to be near Flamminio who courted and then abandoned her. The erotic volatility of the kiss, in sixteenth-century performances exchanged between two young men, one dressed as a woman, the other playing the role of a woman dressed as a man, has captured the imagination of more that one modern critic, as Gl'Ingannati continues to generate interest and pleasure. ${ }^{2}$

The comedy is important to the Anglophone world because Lelia is the first Viola of Twelfth Night, an ingénue who disguises herself as a page in the service of her beloved. Lelia inspired a long line of heroines who play with gender, not merely to pass through the streets unmolested, but to pursue and win the love of a man. In this article I argue that Lelia, who may be read as a stock comic character, also defies the notion of the "theatregram." 3 To account fully for the genesis of this transgressive bourgeois

${ }^{1}$ The kiss occurs in Act II, scene vi. Here I am using Penman's translation, but all other translations of the Gl'Ingannati are from Giannetti and Ruggiero.

${ }^{2}$ Most recently the comedy has been studied by Laura Giannetti, Karen Newman, and Maggie Günsberg. The 2003 translation of the comedy by Giannetti and Ruggiero suggests that the kiss be staged, a more dangerous proposition, at least in the sixteenth century. John Reynolds (or Rainolds), a don at Oxford in Shakespeare's day, warns against the staged kiss because "the kiss of a beautiful boy is like the kiss of 'certain spiders': 'if they do but touch men only with their mouth, they put them to wonderful pain and make them mad"' (Greenblatt, Will in the World, 27).

${ }^{3}$ The term was developed by Louise George Clubb to describe the basic theatrical units of plot or character which Renaissance comic writers combined and recombined in the production of comedies where innovation is for the most part understood as variation of stock elements. 
heroine, who commands audience allegiance as she struts between her female and male identities, requires an examination of the way in which her personal story is bound up with the political situation in Siena during the first half of the sixteenth-century.

First performed during Carnival in 1532, Gl'Ingannati is the second or third play of Gli Intronati (the Thunderstruck or Dunderheads), an academy established by the Sienese elite sometime between 1525-27. The group met with the intention of banishing all thoughts of politics, and dedicating itself entirely to the arts: philosophy, law, music, arithmetic, Greek and Latin literature and the edification of the Tuscan language (Petracchi Costantini, 42). Nevertheless, matters of state do intrude in the three plays composed by an anonymous committee of the academy: $I$ Prigioni, Aurelia, and Gl'Ingannati. ${ }^{4} \mathrm{My}$ concern is not the explicit political content of the comedies, which has already been addressed by Newbigin and Celse-Blanc, but the way in which the political situation in Siena in the years immediately following the Sack of Rome (1527) contributes to the genesis of Lelia.

According to the prologue of Gl'Ingannati, the comedy was composed in three days ["che, quasi in tre dì hanno fatto una commedia" (that they've put this comedy together in barely three days)], for Carnival in 1532.5 Newbigin proposes that a version of the play which did not include the character of the Spanish soldier Giglio may have been in preparation as early as the winter of 1529-30, in expectation of the arrival of Emperor Charles V in Siena (Newbigin, "Politics", 131) —which eventually was postponed. Two years later the academy dusted off the comedy and with minor revisions organized a performance, perhaps in great haste as the pro-logue states. My interpretation of Gl'Ingannati, which places particular emphasis on the scene in which Lelia explains her predicament to the pub-

${ }^{4}$ Precise dating is difficult: I Prigioni, the first comedy of Gli Intronati, and based on Plautus's Captivi, is dated by Newbigin between 1529-30 ("Politics," 124 125). Aurelia, based on Decameron V.5, was composed in the middle of 1531 according to Newbigin, with the exception of the prologue that was added later (Newbigin, "Politics," 128). Celse-Blanc, who edited Aurelia, argues on the basis of internal evidence that the comedy was composed in the summer of 1532 (Accademici, Aurelia, 26). Gl'Ingannati was first performed during Carnival in 1532. This date is supported by the comedy's prologue which "refers to its companion piece, Il Sacrificio, which the 1534 manuscript and all the early editions attribute quite clearly to Epiphany (6 January) 1532" (Newbigin, "Politics," 130-131).

5 All citations of the play are from Borsellino's 1962 edition. 
lic (I.iii), convinces me that the play would not have been suitable entertainment for the emperor and Spanish king, Charles V, with or without the character of Giglio.

The plot, drawn from Plautus's Menaechmi and Bernardo Dovizi's La Calandria, as well as vernacular prose works like the Decameron, concerns the erotic adventures of apparently identical twins who are in fact male and female. ${ }^{6}$ In what is standard fare for comedies, culturally determined gender roles are confused: old men brag about their sexual prowess, a young woman aggressively pursues her lover, not realizing that he is a woman, and two male lovers are passive, one settling for Isabella whom he has known for only an hour and found attractive and wealthy, the other not courting for himself and in the end, entrapped by a pathetic tale of an elderly nursemaid, marrying a woman for whom he has avowed his loathing. The second ingénue, Isabella, barely has a voice at all in the comedy. She is presented through the eyes of servants and her foolish father Gherardo, and the portraits are crude: Gherardo, in a recital rife with unintended irony and sexual innuendo, imagines his daughter to be a meek and pure "colombina" who spends her day before an altar (III.vi), and the servant Pasquella complains that there is nothing worse than serving a young woman in love "so lathered up that she can't find any peace, day or night $[\ldots]$ always scratching between her legs, stroking her thighs, or running up onto the porch or over to the window" (II.ii). Isabella accepts as her husband a man who ressembles the woman she loves; she is tricked by a pretty face and cannot tell sister from brother. Most interesting is Lelia, who not only dresses as a male, but also adopts, at certain points, a detached ironic voice that in Italian literature is strictly the privilege of male protagonists.

Gl'Ingannati inspired more plays and prose works than any other sixteenth-century Italian comedy. Its authors have never been identified, although the academy's comedy committee probably included the play-

${ }^{6}$ Comic twins are already different sexes in Bibbiena's La Calandria. Examples of novelle that may have come into play in the conception of the comedy are Decameron II.3, in which the daughter of the king of England disguises herself as an abbot on a pilgrimage to Rome to escape marriage with the aged king of Scotland, and Decameron II.9, where Ginevra, wife of Bernabo Lomellin, disguises herself as a man to survive in a hostile world and finally bring to justice the villain who has ruined her reputation. Another story in the Decameron that might have inspired the authors of Gl'Ingannati is III.9, an analog of Shakespeare's All's Well that Ends Well, in which Giletta of Nerbona heroically pursues the man she loves, despite his disdain for her. Cerreta cites Bottasso, who sees the influence of Ariosto's I Suppostion the Gl'Ingannati; in this comedy the student Erostrato assumes the role of a servant to gain access to his beloved (Cerreta in La commedia degli Ingannati, 1980, 23). 
wright and letterato Alessandro Piccolomini (1508-1578). Information about early performances is also scarce. After the initial performance, the only other on record in Italy took place in Naples in 1545 (Cerreta in La commedia degli Ingannati, 1980, 17). However, the comedy was published seventeen times in the sixteenth-century (Cerreta in La commedia degli Ingannati, 1980, 34-35). Its publishing success is attributable to a number of factors. The French humanist and theorist Charles Estienne, who translated the comedy into French as Les Abusez and published it in the 1540s, admired its complexity and elegant dénouement. In his translator's introduction, he praises the intrigue of Les Abusez and its Italian model which offers "changing themes, introducing things unexpected and hidden, then disclosing them, leaving one matter to take up another, then returning to the first again, leading everything dexterously and stylishly to the conclusion" (Salingar, Shakespeare, 187). Estienne also praised the scenery and the idiomatic use of Tuscan prose in his play's model, which he tried to imitate in his translation. All this for the spectators' "plaisir incroyable" (Estienne, Les Abusez, iii). Girolamo Ruscelli included Gl'Ingannati in his volume of exemplary Italian comedies in 1554.

Lelia is responsible in large measure for the comedy's success; unlike the majority of unidimensional characters in Renaissance comedy, Lelia becomes, by turns, confused, desperate, reckless and witty. Melzi explains that "from this prototype a new figure is born that will spread throughout the Italian and subsequently, the European stage: the demure, sometimes self-effacing woman who is ready to sacrifice herself for love" (Melzi, "From Lelia," 70). Not demure and self-effacing, according to Giannetti, Lelia is "a major player, a female character who is courageous, clever and strong." Giannetti reads Lelia's transgression in terms of the situation she faces: Lelia, "the daughter of the rich Virginio, brought up in an upperclass household in Modena, cross dresses and takes on the identity of a page named Fabio with the twofold goal, to escape the marriage plans of her father and to be near her beloved Flamminio, who has forgotten her" (Giannetti, "On the Deceptions," 59-60). Cerreta observes that Gl'Ingannati advanced the potential of the comic ingénue on the European stage, from the standard retiring (and indeed often entirely absent) marriageable daughter to that of a prominent character, although two decades after Gl'Ingannati, theorists were still recommending that the "maiden [...] not come to speak on stage" (Cerreta in Accademici, La commedia degli Ingannati, 1980, 24, and quoting Giovan Battista Giraldi Cinthio; my translation). Finally, Gl'Ingannati offers a young man the opportunity to play a man and a woman in the same show, in all likelihood to great comic 
effect and personal Thespian triumph (the heroine Lelia, dressed as herself or as the page Fabio, never appears on the scene with her twin Fabrizio). The comic potential of the role-the flustered confusion of Lelia/Fabio, the swagger of Fabrizio-is written into the script.

Although her strong will and immediate distress are indisputable, early in the comedy we learn why Lelia is different than the typical ingénue. In Act one, Scene three, Lelia, disguised as Fabio, wanders the streets of Modena looking for her nurse Clemenzia whose advice she seeks; the latter is mortified to discover that the young coxcomb trying to catch her attention is, in fact, her charge, Lelia. Reacting to Lelia's attire, Clemenzia demands: "Adunque, hai tu perduto il nome di vergine?" (But have you lost, then, the name of virgin?) Lelia responds with an oblique but stark reference to events that are already familiar to her nurse: "Il nome, no, ch"io sappi, e massimamente in questa terra. Del resto si vuol domandarne gli spagnuoli che mi tenner prigiona a Roma." (The name, no-not as far as I know, especially here in Modena. For the rest, you'll have to ask the Spaniards who held me prisoner in Rome.) The words, startling from the mouth of a comic heroine, reveal a mental landscape that may well have been shared by many Italians in 1529, the setting of the comedy, in the aftermath of the catastrophic Sack of Rome. Here we meet a comic ingénue hinting at a personal history that is anything but protected and innocent.

Lelia explains her decision to diguise herself as a young man in terms of the pain she suffers. Death might be preferable to her present situation.

CLEMENZIA: Io vo' saper perché tu vi vai e perché sei uscita del monistero. Oh! Se tuo padre il sapesse, non t'uccidarebbe, povera te?

LELIA: Mi cavarebbe d'affanni. Tu credi forse ch'io stimi la vita un gran che?

(CLEMENZIA: I want to know why you're running around like this and why you left the convent. Oh, if your father knew, he'd have your head, poor child!

LELIA: That would solve my problem, Do you think I value my life all that much?)

Lelia insists that her misery is the consequence of her thwarted love for Flamminio:

"Oh che sorte è la mia! Amo chi m'ha in odio, chi sempre mi biasma; servo chi non mi conosce; ed aiutolo, per più dispetto, ad amare un'altra."

(Oh, how unlucky I am! I love someone who hates me, who is always cursing me. I serve someone who doesn't even recognize me. And to make matters worse, I help him in his pursuit of another woman). 
Nevertheless, Lelia's devotion to Flamminio is intimately bound to the despair and humiliation she suffered during and after the Sack of Rome. Flamminio saved her from her morbid depression and his love moved her to again take an interest in life.

LELIA: Sai che, dopo il miserabil sacco di Roma, mio padre, perduta ogni cosa e, insieme con la robba, Fabrizio mio fratello, per non restar solo in casa, mi tolse dai servizi della signora marchesana con la quale prima m'aveva posta; e costretti dalla necessità, ce ne tornamo a Modena in casa nostra per fuggir quella fortuna ed a viver di quel poco che avevamo. [...]

CLEMENZIA: Perché mi dici tu quel ch'io so meglio di te? [...]

LELIA: [...] Sai anco quanto, in que' tempi, fu aspra e dura la mia vita e, non pur lontana dai pensieri amorosi, ma quasi da ogni pensiero umano: pensando che, per essere io stata in mano di soldati, che ognuno m'aditasse, né credevo poter vivere sì onestamente che bastasse a far che la gente non avesse che dire.

(LELIA: You know that after the horrible sack of Rome, my father, having lost everything, including my brother Fabrizio, in order not to live alone took me away from the Lady Marchesana in whose service he had left me earlier. Our poverty forced us to return to our home here in Modena to escape our evil fortune and to live as well as we could with what little we had. [...]

CLEMENZIA: Why are you telling me what I know better than you do? [...]

LELIA: [...] You remember also how difficult and hard my life was then. My thoughts were not only far from love but far from virtually everything human. For I was afraid that having been in the hands of Spanish soldiers, everyone would be pointing at me. I was certain that no matter how honorably I lived, people would never stop talking.)

Lelia describes her experience in terms of isolation and morbid shame. The extended period of alienation from people and events taking place around her would probably be decribed as a symptom of post-tramatic stress by modern psychologists. But Lelia is a resiliant young woman. She goes on to recount how the merchant Flamminio, a friend of her father, began to pay attention to her, and even seemed to fall in love with her, and how the love that he inspired rekindled her desire to live.

The scene recounts Lelia's tragedy and establishes her intellectual superiority, an intelligence sharpened by loss and love. Lelia is the only character who is never deceived in Gl'Ingannati, she is the opposite of the architypical comic character, Calandrino, who constantly conflates reality with his own confused reading of signs and his inflated opinion of himself. The space between reality and sign is painfully clear to Lelia. Dressed as a man, she is a woman. Dressed as a man in the manner of a prostitute, she is not 
a fallen woman. A virgin engaged to the wealthy old merchant Gherardo, she may be virgin in name only. She knows the most intimate thoughts of the man she serves with heart and hand; he does not know she exists. Still, Lelia parries with reality and transforms pain with her wit.

\section{CLEMENZIA: Saresti mai diventata femina del mondo?}

LELIA: Sí, che io son del mondo. Quante femine hai tu vedute fuor del mondo? Io, per me, non ci fu' mai, ch'io mi ricordi.

(CLEMENZIA: [...] oh, Lelia, have you become a woman of the world, a whore?

LELIA: Yes, I'm of the world. How many women have you seen from outside the world? As far as I'm concerned, I don't remember ever being outside the world.)

Lelia recognizes herself most definitely as a woman of this fallen world and she is intellectually detached enough to mock the absurdity of the literal phrase. Her ironic collapsing of literal and metaphorical signifiers calls to mind Guido Cavalcanti's "Signori, voi mi potete dire a casa vostra ciò che vi piace" (Gentlemen, in your own house you may say to me whatever you wish). ${ }^{7}$ Lelia tells the audience that she has personally suffered both violation and shame, and yet she is virtuous. Referring to the ranks of

${ }^{7}$ The text is from Boccaccio, Decameron, 757 and the translation from Boccaccio, Decameron, trans. Musa and Bondanella, 401. This kind of detached irony is a trope reserved for male protagonists in Italian literature. Lucrezia in the final scene of the Mandragola, is scornful rather than playful or aloof. Other female protagonists exaggerate irony to the point of sarcasm. For example, in Donato Giannotti's Il Vecchio amoroso (Commedie del Cinquecento, ed. Borsellino, 1-83), an angry Dionora Lanfranchi greets her husband at the door of their home with a smile in III.vi, explaining, "E so ch'egli è obligo delle mogli, quando i mariti tornano, mostrarsi loro di lieta cera, acciò che essi ne piglino allegrezza, con la quale ricompensino i fastidi che hanno fuori" (And I know that it is a duty of wives, when husbands return home, to show a happy face, so that they may draw pleasure from it, by which means they make up for for all the irksome business they attend to while away from home [my translation]). A parallel to Lelia's rhetorical wit occurs in Poggio Bracciolini's letter to Leonardo Bruni in 1416 about the heresy trial of John of Prague at the Council of Constance. According to Poggio, when John is asked about transubstantiation, he responds: "Tum quidam: 'atqui aiunt te dixisse post consecrationem remanere panem;' tum ille: 'apud pistorem remanet panis,' inquit" (Prosatori, 232). [Then someone: But they claim that you said that bread remains after the consecration; then he: Bread remains at the bakery. [my translation]). 
female transvestites who roam the city she demands, "Oh! Fra tante ribalde non ne può andare una buona?" (Oh well, among so many wicked women isn't there room for one good one?).

Giannetti's reading of the same scene focuses on the ambiguous pleasure that Lelia discovers in playing "her masculine masquerade" (Giannetti, "On the Deceptions," 61). Giannetti writes that Lelia, "fascinated from the first with her gioco, seems willing to play in the public space of the city, normally reserved for men, risking her honour as a chaste young woman of good family and/or as a young male page!" (Giannetti, "On the Deceptions," 61). Musing on her plight, Lelia reveals the same lucid and ironic perceptiveness that we hear in her subsequent conversation with Clemenzia: "Oh come mi starebbe bene che qualcun di questi gioveni scapestrati mi pigliasse per forza e, tirandomi in qualche casa, volesse chiarirsi s'io son maschio o femina!" (Oh, it would serve me right if one of those young rogues forced me into one of these houses to see for himself whether I was a boy or a girl!). However, in my reading of the scene, Lelia risks losing the "name" of virgin in this city not only because she is "fascinated from the first with her gioco;" she is willing to gamble because she has already has lost her reputation in her own mind ("For I was afraid that having been in the hands of Spanish soldiers, everyone would be pointing at me."). Lelia does not flinch in her analysis of the desperation of her plight and, like so many characters in the Decameron, from Melchisedech and the Marchioness of Montferrato to Chichibio, she has the wit to transform self-pity and fear into a game that is ultimately productive.

The Sack of Rome defines Lelia's past and future and is in no way secondary to the plot of Gl'Ingannati. The event occured after the defeat of the French army at Pavia in 1525 and the failure of Pope Clement VII's antiimperial League of Cognac (1526). The army of Emperor Charles V, at that point unpaid, hungry, and essentially leaderless, moved rapidly south towards the opulent and fabled Eternal City. The soldiers entered Rome at dawn on 6 May 1527, did not encounter much resistence, and began the brutal destruction of the city and its inhabitants. Luigi Guicciardini found words to express the desperation and resignation of many Italians: "We look at one another like frightened sheep penned up in the slaughterhouse, expecting any moment to see our resources, our families, and our beloved homeland in the hands of barbarous and bestial nations thirsting beyond all limit for our riches and our blood" (Guicciardini, The Sack of Rome, 61). The Sack of Rome signaled the end of any illusion that Italian leadership might possess the political will or intelligence necessary to restore authority. Yet, the Sack of Rome was only the most traumatic point in a long season of war. 
Between 1492 and 1527 Italy became a battleground as France and Spain fought for sovereignty over the peninsula: it was an era of political turmoil, famine-as armies pursued a scorched-earth policy, disease-recurrent plague, the arrival of syphilis from the New World, and precipitous demographic decline.

Given the reduced circumstances of Lelia's father, Virginio, and his natural desire to preserve the money that remained for his son, should Fabrizio have survived, Virginio is only too happy to marry his daughter, who has been in the hands of the Spanish soldiers, to the elderly Gherardo. In Lelia's unblinking assessment of her situation, the anonymous playwrights suggest more profound consequences of the ongoing chaos: despite the appearances of a return to normality in the years following the Sack, the carnivalesque world-upside-down has become permanent in Italy. Virginio has abdicated his paternal role by not protecting his daughter from the soldiers. They stand in his place: uneducated, brutal, peasant-soldiers who, as prison guards, have been granted the authority to protect Lelia's honour or to violate her person. Virginio's name was probably intended to evoke the familiar story of Virginius, the Roman father who ran a dagger through his daughter's breast when he realized that he would not be able to defend her from the lust of the Roman magistrate Appius Claudius.

In Italy, traditional feudal warfare fell victim to a military strategy based on gunpowder. And as Carlyle remarked, gunpowder "makes all men alike tall" (quoted by Fuller, Armament, 83). Without conscription, Spanish, French and Italian armies were composed of mercenaries: professional soldiers as well as peasants, debtors and common criminals granted amnesty when they enlisted. Italians had long resisted the arming of peasants and workers, fearing social upheaval; they relied instead on an old military organization tied to the system of the "condotta" which assigned prominence to traditional feudal forces (Lenzi, Il sacco di Roma, 6). At the beginning of the Italian wars, armies were composed mostly of cavalry, that is, of men wealthy enough to afford a horse and full armour, but by $152890 \%$ of the army was composed of infantry (Fuller, A Military History, 91). Guicciardini noted the change: "nowadays four, six, or twelve thousand untrained foreigners, poorly armed and lacking leadership, harass, consume, and overpower this country of ours" (Guicciardini, The Sack of Rome, 62). "Untrained" is the operative word here: teaching a man to shoot a musket took almost no time compared to training a long bowman, or, of course, a traditional knight. Emperor Charles V, who first invaded Italy in 1516, used Italy as a training ground for his new recruits, before dispatching the soldiers to the Netherlands or Germany (Hale, War and Society, 164). 
In the complex political realignment that followed the Sack of Rome, Charles V could not ignore Siena, a strategically important, pro-imperial city. His principal concern seems to have been that urban violence among the Sienese political factions or monti, and particularly between the proimperial Popolani and pro-French Nove, might compromise his interests there (Celse-Blanc, "Alessandro," 20-22, 33). Charles ordered don Lopes de Soria to the city as ambassador and protector of imperial interests and, following the ouster of Alfonso Piccolomini, Duke of Amalfi, in November 1530 , elevated don Lopes to be the de facto ruler of the city. ${ }^{8}$ The emperor also sent a garrison of soldiers plus a small number of cavalry to Siena. Dandelet has recently suggested that the portrayal of the Spanish soldier as crude and violent is best understood as a literary topos (Dandelet, Spanish Rome, 37), but there is plenty of literary and archival evidence of the hardship suffered by the Sienese in this period at the hands of the Spanish troops.?

The presence of the occupying garrison of armed foot soldiers must have underscored the political impotence of the citizens, their anxiety

${ }^{8}$ Under don Lopes and the military captain don Ferrante Gonzaga, the exiled Nove were restored to power in Siena. The important point is that internal and external politics were inextricably bound as the monti used imperial intervention or French support as a means to acquire power in the city.

${ }^{9}$ In Aurelia, for example, there are various complaints: the servant Famelico (naturally) laments his terrible hunger (I.ii) perhaps caused by the fact that the Spanish do not allow planting to go on (I.iv). Spanish soldiers are accused of burning down homes (I.iv; V.i), and of course the principal complaint is that don Lopes's request is, in fact, a command, whether in military matters or affairs of the heart (I.viii). The Sienese Consiglio generale, 247, 13 October 1530, calls for reform and the return of peace to the city "tanto più quanto lo exercito ogni giorno danegia, sachegia e trascorre tutto il Dominio" (Celse-Blanc in Accademici, Aurelia, 21, n. 42). The entry on 8 January 1531 addresses the financial hardship the billeting of so many soldiers causes: "et perché sono a la guardia de la città 300 fanti et lo illustrissimo Signor Don Lopez ne menarà centocinquanta a li quali bisogna di subbito provedere li denari per essere il tempo de la paga et similmente si trova a servitio di V. S. il capitano Morale con vinticinque cavalli et il bargello con quaranta fanti et dieci cavalli et concorrendo altre infinite spese a la nostra Republica, et trovandosi exaustissima di denari per le disordinate spese et straordinarij travagli passati. Ricorriamo al supremo senato per aiuto in tanta necessità di denari, senza i quali non si può trattenere li stipendiati, né senza loro fare si può; di modo che se di subbito non ci si provede può, nascere scandolo tanto grande quanto immaginare si possa"' (Celse-Blanc in Accademici, Aurelia, 33, n. 87). 
aggravated by the disdain and fear that bourgeois and patricians had always felt towards the urban and rural lower classes, whether Italian or foreign. ${ }^{10}$ A problem of class more than nationality, the Sienese and the Accademia degli Intronati welcomed the Spanish nobility, and in turn the Spanish Emperor Charles V made concessions to loyal Sienese. ${ }^{11}$ Even Don Lopes de Soria was initially received with great pomp and honor (Celse-Blanc in Accademici, Aurelia, 19). The daily reminder of the Spanish victor was the garrison of 300 armed soldiers. In Gl'Ingannati the suggested violation of Lelia captures most viscerally the Sienese's fear of and hatred for the Spanish common soldier. Hostility is also directed towards the soldier in the character of a miles gloriosus who roams the streets and bullies the citizens (or at least their servants) with impunity. Giglio pursues the servant Pasquella, speaking a Spanish interspersed with Italian words, and she responds in Italian. They understand one another perfectly: both are peasants lying through their teeth to cheat each other. Giglio threatens to burn Gherardo's home if Pasquella does not return a rosary he has given her (IV.vi), and he later swears to slash her face for the same reason (V.v ). ${ }^{12}$

${ }^{10}$ Disdain for the poor is a staple in Italian literature. Petrarch criticizes Boccaccio's Lectura dantis as a prostitution of the Muse for the sake of the "feccia plebeia" (Garin in Umanisti, 17-18). Coluccio Salutati describes the popolo minuto who participated in the Ciompi ribellion as "pestis illa" and "truculentissime belue" (Garin in Umanisti, 26).

${ }^{11}$ Evidence of the lack of hostility towards the emperor, at least in principle, is the fact that the Intronati were commissioned by the city to prepare a play in honour of the arrival of the emperor in Siena in 1529-30. Charles V, importuned by prominent Sienese, removed the inimical Don Lopes de Soria from power in March 1531, restored a Piccolomini, the Marchese del Vasto, to command the troops there, and reduced the size of the garrison to a hundred soldiers (CelseBlanc in Accademici, Aurelia, 23). Cerreta pushes the idea of class further, seeing the soldier Giglio as a scapegoat for the humiliating presence of the Spanish soldiers billeted in the city; Giglio courts and harrasses the servants by turns, but the bourgeois and noble characters are spared the boarishness of the common soldier. "Questa scissione sembra provenire da un inconscio desiderio di non contaminare il mondo idealistico e sentimental dell'eroina con elementi farseschi, propri del mondo inferiore della gente meccanica, più volgare e rozzo" (Cerreta in Accademici, La commedia, 30-31). In my opinion, however, Cerreta's reading treats the painful memories expressed by Lelia in I.iii too lightly.

12 Abusive competiveness is not limited to Giglio and Pasquella. All the characters, with the exception of Lelia and Isabella, buttress their intentions with violent threats, and none more than the disappointed lover Flamminio, who will "cut off his [Fabio's] lips and his ears and cut out one of his eyes, and give them all 
A survey of some of the works inspired by Gl'Ingannati reveals the elimination of those aspects of the Sienese comedy most inimical to comic convention or international politics. The soldier Giglio disappears in the first translation of the work and any reference to the violation of Lelia by Spanish soldiers shortly thereafter. Although we know from the prologue to Cecchi's L'Assainolo that the Sack of Rome became a topos to explain the financial and personal disarray of a family at the opening of a comedy, ${ }^{13}$ the actual horrors of the sack are not considered comic material by other writers, and there is certainly no similar account of personal pain from the mouth of a comic ingénue. As a theatregram, the specificity of Lelia's pain is blunted; the many cross dressing heroines she inspired are motivated by love, but not by the desperation to renew a love that had rescued Lelia from her shame and perception of being "far from virtually everything human." As Andrews observes "the dramatists saw their task as to generalize, to pinpoint precisely what might be felt and said by all languishing heroines, rather than to make them and their language startlingly individual" (Andrews, Scripts and Scenarios, 63).

Estienne's early translation of Gl'Ingannati into French, mentioned above, is very faithful to the original, but Giglio and the scenes in which he appears are eliminated. The Spaniard Lope de Rueda uses the essential love intrigue of Gl'Ingannati in Los Engañados (editio princeps 1567), but Lelia's imprisonment during the Sack of Rome and the obnoxious Giglio are cut. The Italian Lelia was thirteen at the time of the sack (I.i), the Spanish Lelia a child. A decade later, as a young woman in love, the Spanish Lelia does not have the intellectual audacity or detachment of her Italian counterpart. In the scene where she reveals her ploy, the Spanish Lelia addresses not her nursemaid, but her tutor Marcelo and proceeds to defend her decision to dress as a man on the basis of fortune and love. The

to her [Isabella] on a plate" (IV.viii). Perhaps we should attribute the verbal violence to comic excess, but it lends a tone of aggressive futility to this "mirror" of the foibles of the upstanding citizens of Modena and their servants. There is also an incongruous reference to the fact that the governor who will not countenance the bearing of arms by citizens (IV.ix).

13“Né sia chi creda, che questa commedia si cominci o dal sacco di Roma, o dall'assedio di Firenze, o da spandimenti di persone, o da sbaragliamento di famiglie, o da altro così fatto accidente" (Cecchi, L'Assiuolo, 113 in Commedie del Cinquecento). ("And don't anyone think that this comedy originates from the Sack of Rome, or from the Siege of Florence, or because persons became displaced, or families had to flee, or some other such event", Cecchi, The Horned Owl, 3). 
playful ingénue has been transformed into a timid and embarrassed maiden. She does not refer to the Sack of Rome in personal terms, but as just retribution for Christian sin. ${ }^{14}$ Lope de Rueda could hardly have been interested in repeating the accusation that Spanish soldiers had raped young girls.

The lapsed Dominican monk Matteo Bandello (1485-1561) retells the story of Lelia as part of his collection of tales published in 1554. ${ }^{15}$ Bandello elaborates on the horrors of the sack almost twenty years after the event.

And to not take more of your time, I say that here in this dear and honorable company there is not one of us who does not fully recall that the Germans and the Spanish sacked Rome so cruelly in the year of our Lord 1527 , and although the sins of that city merited punishment, nevertheless, those who sacked it, being Christians, did not do a good thing, although I understand that the majority were Lutherans, converts, and Jews. Be that as it may, they behaved worse than Turks and committed such enormous and cruel acts against God and His saints that it is impossible to recall without great pain (my translation from Bandello, Tutte le opere, 287).

Despite his attempt to rationalize the event, Bandello does not spare the leadership that allowed soldiers to commit sacrilege, pillage, and rape.

Although the majority of the pillagers and robbers of both sacred and profane things and the rapists of the holy virgins consecrated to Mary were, as has already been said, enemies of the faith of Christ, nevertheless, could those who governed (them) not have prevented so many acts of sacrilege, incest, rape, homicide and other crimes, and realized that many who practiced the violated religion suffered harm? (my translation from Bandello, Tutte le opere, 287).

14"Bien tendréis en la memoria cómo, cuando por nuestros pecados Roma fue saqueada..." (I.ii). ("You well remember how, when Rome was sacked because of our sins..."; my translation). The Spanish Lelia is repeating the widely diffused interpretation of the sack first articulated by Alfonso de Valdés, the imperial secretary, in his Dialogue of Lactancio and an Archdeacon.

${ }^{15}$ There is a link between Gl'Ingannati and the Bandello tale that I have not investigated yet. In his introductory letter Bandello invokes the good memory of Count Guido Rangone, a soldier and Modenese noble who served both Pope Clement VII and the French. In Gl'Ingannati, Lelia refers to the fact that her father was a friend of Guido Rangone, which made him persona non grata to some people in Modena (I.iii). 
The heroine of his tale, renamed Nicuola, does not suffer the fate of Lelia thanks to two Spanish soldiers who wager that her wealthy father might offer a more generous ransom if she is restored to him intact.

Barnabe Riche's "Of Apolonius and Silla," probably the most accessible source of the story for Shakespeare, reflects many of the constituent parts of the original Italian comedy. Silla, daughter of the lord of Cyprus, falls in love with Apolonius, a duke of Constantinople, who had spent some time as a guest in her father's court. When Silla boards a ship for Constantinople in pursuit of Apolonius, her beauty captivates the captain. Seeing no possibility of preserving her virtue, Silla prepares to commit suicide, but is foiled by a violent storm that destroys the ship. She reaches land and resumes the trip to Constantinople, now disguised as her brother, Silvio. Riche's inclusion of the threat of rape suggests that Shakespeare's choice of names, Viola, may actually be a distant evocation of Lelia violata or violée. ${ }^{16}$

Generally we read Italian comedies of the first half of the sixteenthcentury as elite entertainment: the product of the hedonistic, indulgent society that sought to display its cultural superiority and entertain itself as it produced and consumed comedic teatricals. Gl'Ingannati breaks the mold. We rarely hear a voice like Lelia's painful but detatched account of imprisonment and shame. Lelia, the first woman to dress in men's clothes in order to be near her lover, is the most transgressive character in the comedy as well as the most virtuous. She dresses as a man to save her life and to save herself from despair. Lelia's audacity might be compared to Pampinea's, when the latter suggests to her small band of young and unmarried female friends that they leave the corruption of Florence to seek their own survival in the countryside. Although the Decameron was often pillaged for a good (and/or lascivious) tale, as Gherardo himself suggests in the first scene of Gl'Ingannati, one of its essential messages is that in troubled times virtue must be understood in personal terms and that in such times virtue often transcends convention. ${ }^{17}$

${ }^{16}$ This idea was suggested to me by my colleague Matilda Bruckner.

17 In the Decameron, Dioneo reminds us in the conclusion to the Sixth Day, of the need for unconventional solutions in times when common virtue is insufficient: "-Donne, io conosco ciò che io ho imposto non meno che facciate voi, e da imporlo non mi poté istorre quello che voi mi volete mostrare, pensando che il tempo è tale che, guardandosi e gli uomini e le donne d'operar disonestamente, ogni ragionàre è conceduto. Or, non sapete voi che, per la perversità di questa stagione, li giudici hanno lasciati i tribunali? Le leggi, cosí le divine come le umane, tacciono? E ampia licenzia per conservar la vita è conceduta a ciascuno? Per che, se alquanto s'allarga la vostra onestà nel favellare, non per dover con 
Another way we might interpret the invention of a comic character such as Lelia is as a symbol of her authors, the intelligentia of Siena in 153I: colonized but, despite appearances, undefeated, its virtue and wit intact. The comedy may be a political allegory for occupied Siena in the period following the Sack of Rome. In its playfulness it may also be an attempt to heal the wounds of the body politic. Whether it is useful or not to speculate on the political significance of the genesis of a heroine such as Lelia, it is imperative that we recognize that as a comic ingénue she is unique: in her pain, in her personal evocation of a tragic event in Italian history, and in her ironic wit.

\section{Boston College, MA}

\section{Works Cited}

Accademici Intronati di Siena. Gl'Ingannati, vol. 1, pp. 195-289 in Commedie del Cinquecento, ed. Nino Borsellino. Milan: G. Feltrinelli, 1962.

. Gl'Ingannati, 193-287 in Five Italian Renaissance Comedies, ed. and trans. by Bruce Penman. New York: Penguin, 1978.

con l'opere mai alcuna cosa sconcia seguire ma per dar diletto a voi e a altrui, non veggio con che argomento da concedere vi possa nello avvenire riprendere alcuno. Oltre a questo la nostra brigata, dal primo dí infino a questa ora stata onestissima, per cosa che detta ci si sia non mi pare che in atto alcuno si sia maculata né si maculerà con l'aiuto di Dio. Appresso, chi è colui che non conosca la vostra onestà? La quale non che i ragionamenti sollazzevoli ma il terrore della morte non credo che potesse smagare"' (Boccaccio, Decameron, 776-777). ["Ladies, I am aware, no less that you are, of what I have ordered, but the objection you have raised is insufficient to move me to change my mind, for I believe that times are such that as long as ladies and gentlemen take care not to act immorally, every form of speech is permitted. Now, are you not aware that because of the corruption of these times, judges have abandoned their tribunals, the laws, both of God and man, have fallen silent, and everyone is granted free rein to protect his own life? And so, if you were to stretch the bounds of your chastity somewhat with your storytelling, never meaning to follow this with improper actions, but only with the intention of providing pleasure for yourselves and for others, I do not see how in the future any plausible argument could be used to criticize anyone. And besides, from the first day until this very moment, our company has behaved most honorably, regardless of what has been said here, and it does not seem to me that any act whatsoever has sullied our honor, nor, with God's help, will it ever be sullied. Moreover, everyone knows how virtuous you are, and in my opinion no amusing little stories or even the terror of death, for that matter, could make you any less virtuous than you are" (Boccaccio, Decameron, trans. Musa and Bondanella, 401). 
—. La commedia degli Ingannati, ed. Florindo Cerreta. Florence: Leo S. Olschki, 1980.

- Aurelia (comédie anonyme du XVIe siècle), ed. Mireille Celse-Blanc. Paris: Université de la Sorbonne Nouvelle, 1981.

—. Gl'Ingannati, pp. 205-285 in Five Comedies from the Italian Renaissance, ed. and trans. by Laura Giannetti and Guido Ruggiero. Baltimore: Johns Hopkins University Press, 2003.

Andrews, Richard. Scripts and Scenarios. The Performance of Comedy in Renaissance Italy. Cambridge, UK, and New York: Cambridge University Press, 1993.

Bandello, Matteo. Tutte le opere, ed. Francesco Flora. 2 vols. Alessandria: Edizioni dell'Orso, 1993.

Boccaccio, Giovanni. Decameron, ed. Vittore Branca. Turin: Einaudi, c.1980, 1984.

Boccaccio, Giovanni. The Decameron, trans. Mark Musa and Peter Bondanella. New York: Penguin, 1982.

Cecchi, Giovan Maria. L'Assiuolo, vol. 1, pp. 121-194 in Commedie del Cinquecento, ed. Nino Borsellino. Milan: Feltrinelli, 1962.

- The Horned Owl (L'Assiuolo), trans. Konrad Eisenbichler. Carleton Renaissance Plays in Translation. Waterloo: Wilfrid Laurier University Press, 1981.

Celse-Blanc, Mireille. "Alessandro Piccolomini, l'homme du ralliement" pp. 7-76 in Les Écrivains et le pouvoir en Italie à l'époque de la Renaissance, eds. A. Rochon et al. Paris: Université de la Sorbonne Nouvelle, 1972.

Commedie del Cinquecento, ed. Nino Borsellino. 2 vols. Milan: Feltrinelli, 1962.

Dandelet, Thomas James. Spanish Rome, 1500-1700. New Haven: Yale University Press, 2001.

Estienne, Charles. Les Abusez. Comédie faite à la mode des anciens comiques. Paris: Estienne Groulleau, 1548.

Fuller, J. F. C. Armament and History. The Influence of Armament on History from the Dawn of Classical Warfare to the End of the Second World War. New York: Da Capo Press, 1998.

Garin, Eugenio. Umanisti, artisti, scienzati. Studi sul Rinascimento italiano. Rome: Editori Riuniti, 1989.

Giannetti, Laura. "On the Deceptions of the Deceived: Lelia and the Pleasures of Play." Modern Language Notes 116 (2001): 54-73.

Greenblatt, Stephen. Will in the World. How Shakespeare became Shakespeare. New York: Norton, 2004.

Günsberg, Maggie. Gender and the Italian Stage. From the Renaissance to the Present Day. Cambridge, UK, and New York: Cambridge University Press, 1997.

Guicciardini, Luigi. The Sack of Rome, trans. James H. McGregor. New York: Italica Press, 1993.

Hale, J. R. War and Society in Renaissance Europe, 1450-1620. Montreal: McGillQueen's University Press, 1998.

Italian Tales from the Age of Shakespeare. ed. Pamela J.Benson. London: Everyman, 1996. 
Lenzi, Maria Ludovica. Il sacco di Roma del 1527. Florence: La Nuova Italia, 1978. Lope de Rueda. Los engañados. Medora, ed. Fernando Gonzáles Ollé. Madrid: España-Calpe, 1973.

Melzi, Robert C. "From Lelia to Viola." Renaissance Drama 9 (1966): 67-81.

Newbigin, Nerida. "Politics and Comedy in the Early Years of the Accademia degli Intronati of Siena." pp. 123-134 in Il teatro italiano del Rinascimento, ed. Maristella de Panizza Lorch. Milan: Edizioni di Comunità, 1980.

Newman, Karen. "Gl'Ingannati and Shakespeare's Romantic Comedy." Stanford Italian Review 3.2 (1983): 201-11.

Petracchi Costantini, Lolita. L'Accademia degli Intronati di Siena e una sua commedia. Siena: La Diana, 1928.

Prosatori latini del Quattrocento, ed. Eugenio Garin. La letteratura italiana storia e testi, 12. Milan: Ricciardi, 1952.

Ruscelli, Girolamo. Delle comedie elette, novamente raccolte insieme, con le correttioni \& annotationi di Girolamo Ruscelli. Venice: P. Pietrasanta, 1554.

Salingar, Leo. Shakespeare and the Traditions of Comedy. Cambridge, UK, and New York: Cambridge University Press, 1974.

Valdés, Alfonso de. Alfonso de Valdés and the Sack of Rome: Dialogue of Lactancio and an Archdeacon, trans. John E. Longhurst. Albuquerque: University of New Mexico Press, 1952. 
